Jurnal Ilmiah METADATA

\title{
TINJAUAN YURIDIS TINDAK PIDANA PEMILU DAN PROSES PENYELESAIANNYA BERDASARKAN UU NO. 8 TAHUN 2012 TENTANG PEMILIHAN UMUM WILAYAH SUMATERA UTARA
}

\author{
Cut Nurita ${ }^{1)}$, Muhammad Ridwan Lubis ${ }^{2)}$ \\ ${ }^{1)}$ STIH Benteng Huraba \\ ${ }^{2)}$ Universitas Muslim Nusantara Alwashliyah Medan \\ Email: cutnurita123@gmail.com \\ Email: muhammadridwanlubis76@gmail.com
}

\begin{abstract}
ABSTRAK
Dengan diaturnya masalah tindak pidana Pemilihan Umum baik dalam KUH. Pidana maupun dalam UU No. 8 Tahun 2012 menunjukkan bahwa Pemilihan Umum itu merupakan hal yang sangat penting dalam kehidupan bernegara di Indonesia. Juga disadari, bahwa yang yang sangat penting adalah jika Pemilihan Umum tersebut bebas dari tindakan-tindakan yang bertentangan dengan nilai-nilai kejujuran dan keadilan. Dalam penulisan penelitian ini penulis menggunakan metode telaah pustaka (library research) untuk mentelaah data-data sekunder yang berhubungan dengan permasalahan dalam penelitian ini. Berdasarkan pembahasan maka ditarik kesimpulan bahwa pertanggungjawaban pidana pelaku tindak pidana pemilu dalam KUHP adalah apabila melakukan ancaman kekerasan, merintangi seseorang melakukan hak pilihnya, melakukan penyuapan terhadap seseorang dengan maksud agar tidak menjalankan hak pilihnya, melakukan penipuan yang menyebabkan hak pilih seseorang menjadi tidak berharga, melakukan pemalsuan identitas dan melakukan penipuan yang menyebabkan hasil pemungutan suara menjadi lain seolaholah suara-suara yang diberikan sah. Pertanggungjawaban dan penyelesaian tindak pidana kampanye di luar prosedur dalam UU No. 8 Tahun 2012 dan mekanisme penyelesaian dalam UU No. 8 Tahun 2012 yang dilakukan Yenny Pardede da Ety Mulyati dinyatakan telah melakukan tindak pidana melanggar perkara kampanye Pemilu Pasal 270 dan Pasal 274 sebagaimana diatur dalam Pasal 137 ayat (4) Undang-Undang Nomor 10 Tahun 2008 tentang Pemilihan Umum Anggota Dewan Perwakilan Rakyat, Dewan Perwakilan Rakyat Daerah, dan Dewan Perwakilan Rakyat Daerah.
\end{abstract}

Kata Kunci : Tinjauan Yuridis, Tindak Pidana, Pemilu

\section{PENDAHULUAN}

Pemilihan umum sebagai sarana untuk menyalurkan aspirasi rakyat merupakan wujud paling nyata sebagai pelaksanaan demokrasi. Oleh itu sudah selayaknya ditentang dan ditindak segala perbuatan yang bermaksud membuat Pemilihan Umum itu menjadi tidak demokratis (tidak jujur dan tidak adil). 


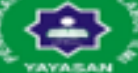

\section{Jurnal Ilmiah METADATA}

Sebagai upaya awal untuk mencegah tindakan-tindakan yang tidak demokratis terhadap pelaksanaan Pemilihan Umum telah diatur dalam KUH. Pidana Buku II Bab IV tentang kejahatan terhadap pelaksanaan kewajiban dan hak kenegaraan. Demikian pula juga telah diatur dalam Undang-Undang Nomor 4 Tahun 2000 dan Undang-Undang Nomor 8 Tahun 2012 Tentang Pemilihan Umum Anggota Dewan Perwakilan Rakyat, Dewan Perwakilan Daerah, Dan Dewan Perwakilan Rakyat Daerah.

Dengan diaturnya masalah tindak pidana dalam Pemilihan Umum baik dalam KUH. Pidana maupun dalam UU No. 8 Tahun 2012 menunjukkan bahwa Pemilihan Umum itu merupakan hal yang sangat penting dalam kehidupan bernegara di Indonesia. Juga disadari, bahwa yang yang sangat penting adalah jika Pemilihan Umum tersebut bebas dari tindakan-tindakan yang bertentangan dengan nilai-nilai kejujuran dan keadilan.

Tindak pidana dalam Pemilihan Umum memang memiliki ciri yang khas atau spesifik jika dibandingkan dengan tindak pidana pada umumnya. Sebab tindak pidana Pemilihan Umum hanya mungkin terjadi ketika diadakan pemilihan umum atau dalam pelaksanaan masa kampanye Pemilihan Umum. Sedangkan tindak pidana lain seperti pencurian, pembunuhan dan korupsi, bisa terjadi setiap waktu.

\section{METODE PENELITIAN}

Penelitian ini tergolong sebagai penelitian hukum normatif. Data penelitian ini bersumber dari data sekunder yang bersumber dari bahan-bahan hukum, yang terdiri dari bahan hukum primer, sekunder dan tersier. Penelitian ini menggunakan pendekatan undang-undang dan pendekatan konseptual. Analisis data dalam penelitian ini menggunakan analisis data kualitatif.

\section{HASIL DAN PEMBAHASAN}

\section{A. Gambaran Umum Tentang Pemilu.}




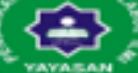

\section{Jurnal Ilmiah METADATA}

Pasal 1 ayat (2) Undang-Undang Dasar Negara Republik Indonesia Tahun 1945 menyatakan bahwa "kedaulatan berada di tangan rakyat dan dilaksanakan menurut Undang-Undang Dasar". Makna dari "kedaulatan berada di tangan rakyat" adalah bahwa rakyat memiliki kedaulatan, tanggung jawab, hak dan kewajiban untuk secara demokratis memilih pemimpin yang akan membentuk pemerintahan guna mengurus dan melayani seluruh lapisan masyarakat, serta memilih wakil rakyat untuk mengawasi jalannya pemerintahan. Perwujudan kedaulatan rakyat dilaksanakan melalui Pemilu secara langsung sebagai sarana bagi rakyat untuk memilih wakilnya yang akan menjalankan fungsi melakukan pengawasan, menyalurkan aspirasi politik rakyat, membuat undang-undang sebagai landasan bagi semua pihak di Negara Kesatuan Republik Indonesia dalam menjalankan fungsi masing-masing, serta merumuskan anggaran pendapatan dan belanja untuk membiayai pelaksanaan fungsifungsi tersebut.

Pemilihan Umum selanjutnya disebut Pemilu adalah sarana pelaksanaan kedaulatan rakyat yang dilaksanakan secara langsung, umum, bebas, rahasia, jujur, dan adil dalam Negara Kesatuan Republik Indonesia berdasarkan Pancasila dan Undang-Undang Dasar Negara Republik Indonesia Tahun1945.

Djoko Prakoso menyebutkan bahwa yang dimaksud dengan pemilihan umum adalah "sarana pelaksanaan asas kedaulatan rakyat dalam negara Republik Indonesia. Pemlihan umum yang dilaksanakan berdasarkan demokrasi Pancasila dengan mengadakan pemungutan suara secara langsung, umum, bebas dan rahasia. ${ }^{9}$

Pemilihan Umum adalah sarana pelaksanaan kedaulatan rakyat dalam Negara Kesatuan Republik Indonesia yang berdasarkan Pancasila dan Undang-Undang Dasar Negara Republik Indonesia Tahun $1945 .^{10}$

${ }^{8}$ R. Herlambang Perdana Wiratraman, Pemilihan Umum, Fakultas Hukum, Universitas Airlangga, Surabaya, 2008, h.5

${ }^{9}$ Djoko Prakoso., Tindak Pidana Pemilu, Rajawali Pers, Jakarta, 2001, h.119

10 Topo Santoso, Tindak Pidana Pemilu, Jakarta, Sinar Grafika,2006., h. 6 


\section{Jurnal Ilmiah METADATA}

Pemilu merupakan sarana perwujudan untuk menghasilkan wakil rakyat yang aspirastif, berkualitas dan bertanggungjawab berdasarkan Pancasila dan UndangUndang Dasar Negara RI Tahun 1945. Pemilihan umum sebagai pelaksanaan kedaulatan rakyat dimana rakyat dapat memilih pemimpin politik secara langsung. Yang dimaksud dengan pemimpin politik disini adalah wakil-wakil rakyat yang duduk di lembaga perwakilan rakyat (parlemen) baik ditingkat pusat maupun daerah dan pemimpin lembaga eksekutif atau kepala pemerintahan seperti presiden, gubernur, atau bupati/walikota.

Menurut Undang-Undang Nomor 8 Tahun 2012 Tentang Pemilihan Umum Anggota Dewan Perwakilan Rakyat, Dewan Perwakilan Daerah, Dan Dewan Perwakilan Rakyat Daerah bahwa Pemilihan Umum adalah sarana pelaksanaan kedaulatan rakyat yang dilaksanakan secara langsung, umum, bebas, rahasia, jujur, dan adil dalam Negara Kesatuan Republik Indonesia berdasarkan Pancasila dan Undang-Undang Dasar Negara Republik Indonesia Tahun 1945.

Pemilu untuk memilih anggota Dewan Perwakilan Rakyat, Dewan Perwakilan Daerah, dan Dewan Perwakilan Rakyat Daerah diselenggarakan berlandaskan asas langsung, umum, bebas, rahasia, jujur, dan adil setiap lima tahun sekali. Pemilu diselenggarakan dengan menjamin prinsip keterwakilan, yang artinya setiap orang Warga Negara Indonesia dijamin memiliki wakil yang duduk di lembaga perwakilan yang akan menyuarakan aspirasi rakyat di setiap tingkatan pemerintahan, dari pusat hingga ke daerah. Pemilu yang terselenggara secara langsung, umum, bebas, rahasia, jujur, dan adil merupakan syarat mutlak untuk mewujudkan wakil rakyat yang berkualitas, dapat dipercaya, dan dapat menjalankan fungsi kelembagaan legislatif secara optimal. Penyelenggaraan Pemilu yang baik dan berkualitas akan meningkatkan derajat kompetisi yang sehat, partisipatif, dan keterwakilan yang makin kuat dan dapat dipertanggungjawabkan.

Penyelenggaraan Pemilu sangatlah penting bagi suatu negara, hal ini disebabkan karena : 


\section{$\rightarrow$}

\section{Jurnal Ilmiah METADATA}

a. Pemilu merupakan sarana perwujudan kedaulatan rakyat.

b. Pemilu merupakan sarana untuk melakukan penggantian pemimpin secara kontitusional.

c. Pemilu merupakan sarana bagi pemimpin politik untuk memperoleh legitimasi.

d. Pemilu merupakan sarana bagi rakyat untuk berpartisipasi dalam proses politik. $^{11}$

Tujuan dari pada penyelenggaraan pemilihan umum (general election) dapat dirumuskan dalam empat bagian yakni:

1. Untuk memungkinkan terjadinya pemilihan kepemimpinan pemerintahan secara tertib dan damai.

2. Untuk memungkinkan terjadinya pergantian pejabat yang akan mewakili kepentingan rakyat di lembaga perwakilan.

3. Untuk melaksanakan prinsip kedaulatan rakyat.

4. Untuk melaksanakan prinsip hak-hak asasi warga negara.

Kegiatan pemilihan umum merupakan salah satu sarana penyaluran hak asasi. $^{12}$ warga Negara yang prinsipil. Dalam rangka pelaksanaan hak asasi warga Negara adalah keharusan bagi pemerintah untuk menjamin terlaksananya penyelenggaran pemilu sesuai dengan jadwal ketatanegaraan yang telah ditentukan. Sesuai dengan prinsip kedaulatan rakyat dimana rakyatlah yang berdaulat, semua aspek penyelenggaraan pemilu, harus dikemablikan kepada rakyat untuk menentukannya. Adalah pelanggaran terhadap hak asasi apabila pemerintah tidak menjamin terselenggaranya pemilhan umum, memperlambat penyelenggaraan pemilu tanpa perseteujuan para wakil rakyat.

Pemilihan umum di Indonesia menganut asas "Luber" yang merupakan singkatan dari "Langsung, Umum, Bebas dan Rahasia". Asal "Luber" sudah ada sejak zaman Orde Baru. Langsung berarti pemilih diharuskan memberikan suaranya secara langsung dan tidak boleh diwakilkan. Umum berarti pemilihan umum dapat diikuti seluruh warga negara yang sudah memiliki hak menggunakan suara. Bebas berarti

${ }^{11}$ Tomi Tresnady, Modul Pemilihan Umum untuk Pemula, Sinar Grafiti, Jakarta, 2010, h.8

${ }^{12}$ Ibid, h.11. 


\section{$2 \rightarrow$}

\section{Jurnal Ilmiah METADATA}

pemilih diharuskan memberikan suaranya tanpa ada paksaan dari pihak manapun, kemudian Rahasia berarti suara yang diberikan oleh pemilih bersifat rahasia hanya diketahui oleh si pemilih itu sendiri.

Kemudian di era reformasi berkembang pula asas "Jurdil" yang merupakan singkatan dari "Jujur dan Adil". Asas jujur mengandung arti bahwa pemilihan umum harus dilaksanakan sesuai dengan aturan untuk memastikan bahwa setiap warga negara yang memiliki hak dapat memilih sesuai dengan kehendaknya dan setiap suara pemilih memiliki nilai yang sama untuk menentukan wakil rakyat yang akan terpilih. Asas adil adalah perlakuan yang sama terhadap peserta pemilu dan pemilih, tanpa ada pengistimewaan ataupun diskriminasi terhadap peserta atau pemilih tertentu. Asas jujur dan adil mengikat tidak hanya kepada pemilih ataupun peserta pemilu, tetapi juga penyelenggara pemilu.

Dengan asas langsung, rakyat sebagai Pemilih mempunyai hak untuk memberikan suaranya secara langsung sesuai dengan kehendak hati nuraninya, tanpa perantara. Pemilihan yang bersifat umum mengandung makna menjamin kesempatan yang berlaku menyeluruh bagi semua warga negara, tanpa diskriminasi berdasarkan suku, agama, ras, golongan, jenis kelamin, kedaerahan, pekerjaan, dan status sosial. Setiap warga negara yang berhak memilih bebas menentukan pilihannya tanpa tekanan dan paksaan dari siapa pun. Di dalam melaksanakan haknya, setiap warga negara dijamin keamanannya oleh negara, sehingga dapat memilih sesuai dengan kehendak hati nurani. Dalam memberikan suaranya, Pemilih dijamin bahwa pilihannya tidak akan diketahui oleh pihak mana pun. Pemilih memberikan suaranya pada surat suara dengan tidak dapat diketahui oleh orang lain. Dalam penyelenggaraan Pemilu ini, penyelenggara Pemilu, aparat pemerintah, Peserta Pemilu, pengawas Pemilu, pemantau Pemilu, Pemilih, serta semua pihak yang terkait harus bersikap dan bertindak jujur sesuai dengan ketentuan peraturan perundangundangan. Setiap Pemilih dan Peserta Pemilu mendapat perlakuan yang sama, serta bebas dari kecurangan pihak mana pun. 


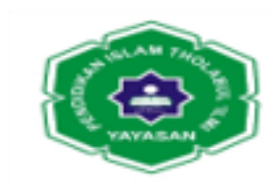

\section{Jurnal Ilmiah METADATA}

\section{Gambaran Umum Tentang Tindak Pidana Pemilu}

Seperti diketahui bahwa istilah het strafbare feit telah diterjemahkan dalam bahasa Indonesia yang artinya antara lain sebagai berikut :

a. Perbuatan yang dapat/boleh dihukum.

b. Peristiwa pidana

c. Perbuatan pidana

d. Tindak pidana. ${ }^{13}$

Tentang apa yang diartikan dengan strafbaar feit (tindak pidana) para sarjana memberikan pengertian yang berbeda-beda.

Simons merumuskan strafbaar feit adalah :

Suatu handeling (tindakan atau perbuatan) yang diancam dengan pidana oleh Undang-Undang, bertentangan dengan hukum (onrechtmatig) dilakukan dengan kesalahan schuld oleh seseorang yang mampu bertanggung jawab. Kemudian beliau membaginya dalam dua golongan unsur yaitu :

a. Unsur-unsur objektif yang berupa tindakan yang dilarang/diharuskan.

b. Unsur subjektif yang berupa kesalahan dan kemampuan bertanggung jawab. $^{14}$

Menurut Van Hamel merumuskan strafbaar feit itu sama dengan yang dirumuskan oleh Simons, hanya ditambahkannya dengan kalimat 'tindakan mana bersifat dapat dipidana'. Perumusan VOS bahwa strafbaar feit adalah suatu kelakuan (gedraging) manusia yang dilarang dan oleh Undang-Undang diancam dengan pidana. $^{15}$

\section{Mulyatno menyebutkan bahwa :}

Tindak pidana adalah perbuatan yang oleh aturan hukum pidana dilarang dan diancam dengan pidana barang siapa yang melanggar larangan tersebut. Selanjutnya Mulyatno menyebutkan bahwa menurut wujudnya atau sifatnya, perbuatan-perbuatan pidana ini adalah perbuatan-perbuatan yang melawan

13 Adami Chazawi., Pelajaran Hukum Pidana Bagian I, PT. Raja Grafindo Persada, Jakarta, 2000 , h.26

${ }^{14}$ Ibid., h. 27

${ }^{15}$ Ibid, h. 28 . 


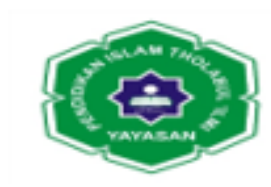

\section{Jurnal Ilmiah METADATA}

hukum, merugikan masyarakat dalam arti bertentangan dengan atau menghambat akan terlaksananya tata dalam pergaulan masyarakat yang dianggap baik dan adil. $^{16}$

Menurut Tim Pengkajian Hukum Pidana Nasional menyebutkan bahwa tindak pidana adalah perbuatan melakukan atau tidak melakukan sesuatu yang oleh peraturan perundang-undangan dinyatakan sebagai perbuatan yang dilarang dan diancam dengan pidana. ${ }^{17}$

R. Soesilo menyebutkan bahwa tindak pidana adalah sesuatu perbuatan yang dilarang atau diwajibkan oleh Undang-Undang yang apabila dilakukan atau diabaikan, maka orang yang melakukan atau mengabaikan itu diancam dengan hukuman. ${ }^{18}$

Menurut M. Hamdan tindak pidana itu juga terdiri dari dua unsur yaitu sebagai berikut :

a. Unsur yang bersifat objektif yang meliputi :

1) Perbuatan manusia yaitu perbuatan yang positif atau suatu perbuatan yang negatif yang menyebabkan pidana.

2) Akibat perbuatan manusia yaitu akibat yang terdiri atas merusakkan atau membahayakan kepentingan-kepentingan hukum yang menurut norma hukum itu perlu ada supaya dapat dihukum.

3) Keadaan-keadaan sekitar perbuatan itu, keadaan-keadaan ini bisa jadi terdapat pada waktu melakukan perbuatan.

4) Sifat melawan hukum dan sifat dapat dipidanakan perbuatan itu melawan hukum, jika bertentangan dengan undang-undang.

b. Unsur yang bersifat subjektif yaitu unsur yang ada dalam diri si pelaku itu sendiri yaitu kesalahan dari orang yang melanggar aturan-aturan pidana, artinya pelanggaran itu harus dapat dipertanggung jawabkan kepada pelanggar. ${ }^{19}$

Suatu perbuatan akan menjadi suatu tindak pidana apabila perbuatan tersebut mengandung unsur-unsur :

\footnotetext{
${ }^{16}$ Mulyatno, Asas-Asas Hukum Pidana, Bina Aksara, Jakarta, 1987, h.54

${ }^{17}$ Ibid, h.56

${ }^{18}$ R. Soesilo,Kitab Undang-Undang Hukum Pidana, Politea, Bogor, 1998, h.26

19 M. Hamdan., Tindak Pidana Suap dan Money Politics, Pustaka Bangsa Press, Medan,
} 2005, h.9 


\section{$2 \rightarrow$}

rarnizan

\section{Jurnal Ilmiah METADATA}

a. Melawan hukum

b. Merugikan masyarakat

c. Dilarang oleh aturan pidana

d. Pelakunya diancam dengan hukuman pidana. ${ }^{20}$

Suatu hal yang memastikan bahwa perbuatan itu menjadi suatu tindak pidana adalah dilarang oleh aturan pidana dan pelakunya diancam dengan pidana, sedangkan melawan hukum dan merugikan masyarakat menunjukkan sifat perbuatan tersebut. Suatu perbuatan yang bersifat melawan hukum dan merugikan masyarakat belum tentu hal itu merupakan suatu tindak pidana sebelum dipastikan adanya larangan atau aturan pidananya (Pasal 1 KUH.Pidana) yang diancamkan terhadap pelakunya. Perbuatan yang bersifat melawan hukum dan yang merugikan masyarakat banyak sekali, tetapi baru masuk dalam lapangan hukum pidana apabila telah ada larangan oleh peraturan pidana dan pelakunya diancam dengan hukuman.

\section{E. Pertanggungjawaban Pidana Pelaku Tindak Pidana Pemilu Dalam KUHP}

Pertanggungjawaban pidana dalam bahasa asing di sebut sebagai "toerekenbaarheid," "criminal reponsibilty," "criminal liability," pertanggungjawaban pidana disini di maksudkan untuk menentukan apakah seseorang tersebut dapat di pertanggungjawabkan atasnya pidana atau tidak terhadap tindakan yang dilakukanya itu. $^{28}$

Menurut Roeslan Saleh, dalam pengertian perbuatan pidana tidak termasuk pertanggungjawaban.Perbuatan pidana menurut Roeslan Saleh mengatakan, orang yang melakukan perbuatan pidana dan memang mempunyai kesalahan merupakan dasar adanya pertanggungjawaban pidana. Asas yang tidak tertulis mengatakan, "tidak di ada pidana jika tidak ada kesalahan," merupakan dasar dari pada di pidananya si pembuat. ${ }^{29}$

${ }^{20}$ Ibid, h. 10

28 S.R Sianturi .Asas-asas Hukum Pidana Indonesia dan Penerapanya, Alumni AhaemPeteheam, Jakarta, 1996, h .245

${ }^{29}$ Djoko Prakoso .Asas-asas Hukum Pidana di Indonesia. Liberty, Yogyakarta, 1987, h.75 


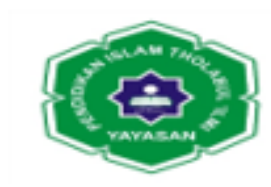

\section{Jurnal Ilmiah METADATA}

Seseorang melakukan kesalahan, menurut Djoko Prakoso, jika pada waktu melakukan delik, dilihat dari segi masyarakat patut di cela. Dengan demikan, menurutnya seseorang mendapatkan pidana tergantung pada dua hal, yaitu :

1. Harus ada perbuatan yang bertentangan dengan hukum, atau dengan kata lain, harus ada unsur melawan hukum.jadi harus ada unsur Obejektif.

2. Terhadap pelakunya ada unsur kesalahan dalam bentuk kesengajaan dan atau kealpaan, sehingga perbuatan yang melawan hukum tersebut dapat di pertanggungjawabkan kepadanya.jadi ada unsur subjektif. ${ }^{30}$

Perbuatan pidana memiliki konsekuensi pertanggungjawaban serta penjatuhan pidana.

Setidaknya ada dua alasan mengenai hakikat kejahatan, yakni pertama pendekatan yang melihat kejahatan sebagai dosa atau perbuatan yang tidak senonoh yang di lakukan manusia lainya. Kedua pendekatan yang melihat kejahatan sebagai perwujudan dari sikap dan pribadi pelaku yang tidak normal sehingga ia berbuat jahat. ${ }^{31}$

Kedua pendekatan ini berkembang sedemikian rupa bahkan di yakini mewakili pandangan-pandangan yang ada seputar pidana dan pemidanaan. Dari sinilah kemudian berbagai perbuatan pidana dapat di lihat sebagai perbuatan yang tidak muncul begitu saja, melainkan adalah hasil dari refleksi dan kesadaran manusia. Hanya saja perbuatan tersebut telah menimbulkan kegoncangan sosial di masyarakat.

Didalam hal kemampuan bertanggungjawab bila di lihat dari keadaan batin orang yang melakukan perbuatan pidana merupakan masalah kemampuan bertanggungjawab dan menjadi dasar yang penting untuk menentukan adanya kesalahan, yang mana keadaan jiwa orang yang melakukan perbuatan pidana haruslah sedemikian rupa sehingga dapat dikatakan normal, sebab karena orang yang normal, sehat inilah yang dapat mengatur tingkah lakunya sesuai dengan ukuran - ukuran yang di anggap baik oleh masyarakat. ${ }^{32}$

Sementara bagi orang yang jiwanya tidak sehat dan normal, maka ukuranukuran tersebut tidak berlaku baginya tidak ada gunanya untuk di adakan

${ }^{30}$ Ibid, h.76

31 Andi Hamzah, Bunga Rampai Hukum Pidana dan Acara Pidana, Ghalia Indonesia Jakarta, 1986, h. 78

${ }^{32}$ Ibid, h. 79 


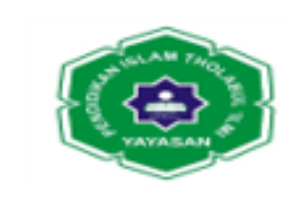

\section{Jurnal Ilmiah METADATA}

pertanggungjawaban, sebagaimana ditegaskan dalam ketentuan Bab III Pasal 4 KUHP yang berbunyi sebagai berikut :

1. Barang siapa mengerjakan sesuatu perbuatan, yang tidak dapat di pertanggungjawabkan kepadanya karena kurang sempurna akalnya atau karena sakit berubah akal tidak boleh di hukum

2. Jika nyata perbuatan itu tidak dapat di pertanggungjawabkan kepadanya karena kurang sempurna akalnya karena sakit berubah akal maka hakim boleh memerintahkan menempatkan di di rumah sakit gila selama-lamanya satu tahun untuk di periksa.

3. Yang di tentukanya dalam ayat di atas ini, hanya berlaku bagi Mahkamah Agung, Pengadilan Tingi dan pengadilan negeri.

Simons mengatakan bahwa mampu bertanggungjawab adalah mampu menginsafi sifat melawan hukumnya perbuatan dan sesuai dengan ke insafan itu menentukan kehendaknya. ${ }^{33}$ Adapun menurut Andi Hamzah, untuk adanya kemampuan beranggungjawab maka harus ada dua unsur yaitu :

1. Kemampuan untuk membeda-bedakan antara perbuatan yang baik dan buruk, yang sesuai dengan hukum dan yang melawan hokum.

2. Kemampuan untuk menentukan kehendaknya menurut keinsafan tentang baik dan buruknya perbuatan tadi. ${ }^{34}$

Dengan kata lain, bahwa kemampuan bertanggungjawab berkaitan dengan dua faktor terpenting, yakni pertama faktor akal untuk membedakan antara perbuatan yang di perbolehkan dan yang di larang atau melanggar hukum, dan kedua faktor perasaan atau kehendak yang menetukan kehendaknya dengan menyesuaikan tingkah lakunya dengan penuh kesadaran.

1. Kesalahan

Dipidananya seseorang tidaklah cukup orang itu telah melakukan perbuatan yang bertentangan dengan hukum atau bersifat melawan hukum. Jadi meskipun perbuatanya memenuhi rumusan delik dalam undang-undang dan tidak di benarkan,

\footnotetext{
33 J.E. Sahetapy, Victimilogy Sebuah Bunga Rampai, Sinar Harapan, Jakarta, 1998, h.41-42

${ }^{34}$ Andi Hamzah, Op.Cit, h.81
} 


\section{라}

ravasang

\section{Jurnal Ilmiah METADATA}

hal tersebut belum memenuhi syarat untuk penjatuhan pidana.Untuk itu pemidanaan masih perlu adanya syarat, yaitu bahwa orang yang melakukan perbuatan itu mempunyai kesalahan atau bersalah.

Di sini berlaku apa yang di sebut atas "Tiada Pidana Tanpa Kesalahan" (keine strafe ohne schhuld atau geen straf zonder schuld) atau Nulla Poena Sine Culpa (Culpa) di sini dalam arti luas meliputi kesengajaan). Dari apa yang telah di sebutkan di atas, maka dapat di katakan bahwa kesalah terdiri atas beberapa unsur ialah :

a. Adanya kemampuan bertanggungjawab pada si pembuat (Schuldfahigkeit atau Zurechnungsfahigkeit) : artinya keadaan jiwa si pembuat harus normal.

b. Hubungan batin antara si pembuat dengan perbuatanya berupa kesengajaan (dolus) atau keapaan (culpa) : ini di sebut bentuk-bentuk kesalahan.

c. Tidak adanya alasan yang menghapus kesalahan atau tidak ada alasan pemaaf. $^{35}$

Jika ketiga unsur ada maka orang yang bersangkutan bisa di nyatakan bersalah atau mempunyai pertanggungjawaban pidana, sehingga bisa dipidana. ${ }^{36}$ Sekalipun kesalahan telah di terima sebagai unsur yang menentukan pertanggungjawaban pembuat tindak pidana, tetapi mengenai bagaimana memaknai kesalahan masih terjadi saling perdebatan di kalangan para ahli.Pemahaman yang berbeda mengenai makna kesalahan, dapat menyebakan perbedaan dalam penerapanya.

Dengan kata lain, pengertian tentang kesalahan dengan sendirnya menentukan ruang lingkup pertanggungjawaban pembuat tindak pidana. Dalam pengertian tindak pidana termasuk pertanggungjawaban pidana. Tindakan pidana hanya menunjuk kepada dilarang dan di ancamnya perbuatan dengan suatu pidana. Namun orang yang melakukan tindak pidana belum tentu di jatuhi pidana sebagaimana yang di ancamkan, hal ini tergantung pada " apakah dalam melakukan perbuatan ini orang tersebut mempunyai kesalahan, "yang merujuk kepada asas dalam

${ }^{35}$ Sudarto, Hukum Pidana dan Perkembangan Masyarakat, Sinar Baru, Bandung, 1983, h.77

${ }^{36} \mathrm{Ibid}$, h.78 


\section{란?}

\section{Jurnal Ilmiah METADATA}

pertanggungjawaban dalam hukum pidana." "Tidak di pidana jika tidak ada kesalahan (geen straf zonder schuld:actus non facit reum nisi mens sir rea)". ${ }^{37}$

Moeljatno menjelaskan bahwa orang yang tidak dapat di persalahkan melanggar sesuatu tindak pidana tidak mungkin di kenakan pidana, meskipun orang tersebut di kenal buruk perangainya, kikir, tidak suka menolong orang lain,sangat ceroboh, selama dia tidak melanggar larangan pidana. ${ }^{38}$ Demikian pula meskipun melakukan tindak pidana, tidak selalu dapat di pidana. Misalnya, seorang anak yang bermain dengan korek api dan menyalakan di dinding rumah tetangganya sehingga menimbulkan bahaya umum baik terhadap barang maupun orang (Pasal 187 KUHP). Walaupun anak tersebut yang membakar rumah tetangga atau setidaknya karena perbuatan anak tersebut rumah tentangga terbakar (pasal $188 \mathrm{KUHP}$ ). Anak tersebut tidak dapat di mintai pertanggungjawaban atas perbuatanya itu.

Van Hammel mengatakan bahwa "kesalahan dalam suatu delik merupakan pengertian psychologis, perhubungan antara keadaan si pembuat dan terwujudnya unsur-unsur delik karena perbuatanya". Kesalahan adalah pertanggungjawaban dalam hukum (schuld is de verantwoordelijkeheid rechtens). ${ }^{39}$ Simons menyebutkan bahwa kesalahan adalah adanya keadaan physchis yang tertentu pada orang yang melakukan tindak pidana dan adanya hubungan antara keadaan tersebut dengan perbuatan yang di lakukan sedemikan rupa, hingga orang itu dapat dicela karena melakukan perbuatan tadi. ${ }^{40}$ Dengan demikian untuk adanya suatu kesalahan harus di perhatikan dua hal di samping melakukan tindak pidana, yakni :

a. Adanya keadaan Phychis( bathin) yang tertentu.

b. Adanya hubungan tertentu antara keadaan bathin tersebut dengan perbuatan yang di lakukan, hingga menimbulkan celaaan tadi. ${ }^{41}$ 1983 , h.83

${ }^{37}$ Roeslan Saleh, Perbuatan Pidana dan Pertanggungjawaban Pidana, Aksara Baru, Jakarta,

${ }^{38}$ Mulyatno, Asas-Asas Hukum Pidana, Bina Aksara, Jakarta, 1987, h.52

39 Sudarto, Op.Cit, h.91

${ }^{40}$ Ibid, h. 92

${ }^{41}$ Ibid, h.92 


\section{라}

\section{Jurnal Ilmiah METADATA}

\section{Dolus (Dengan Sengaja)}

Dalam kiatb Undang-undang Hukum Pidana ( Criminal wetboek) tahun 1809 di cantumkan : "sengaja ialah kemauan untuk melakukan atau tidak melakukan perbuatan yang di larang atau di perintahkan oleh Undang-undang." Dalam memorie Van Toelichting (Mvt) Menteri Kehakiman sewaktu pengajuan criminal Wetboek tahun 1881 (yang menjadi kitab Undang-undang Hukum Piadan Indonesia 1915), dijelaskan : "sengaja " diartikan : "dengan sadar dari kehendak melakukan suatu kejahatan tertentu." 42

Beberapa sarjana merumuskan de will sebagai keinginan, kemauan, kehendak, dan perbuatan merupakan pelaksanaan dari kehendak. De will (kehendak) dapat tujukan terhadap perbuatan yang dilarang dan akibat yang di larang. Ada dua teori yang berkaitan dengan pengertian "sengaja" yaitu teori kehendak dan teori pengetahuan atau membayangkan. ${ }^{43}$

Menurut teori pengetahuan atau teori membayangkan, manusia tidak mungkin dapat menghendaki suatu akibat karena manusia tidak mungkin dapat menghendakai suatu akibat karena manusia hanya dapat menginginkan, mengharapakan atau membayangkan adanya suatu akibat. Adalah "sengaja" apabila suatu akibat yang di timbulkan karena suatu tindakan di bayangkan sebagai maksud tindakan itu dan karena itu tindakan yang bersangkutan di lakukan sesuai dengan bayangan yang terlebih dahulu telah di buat. Teori ini menitik beratkan pada apa yang di ketahui atau di bayangkan si pembuat, ialah apa yang akan terjadi pada waktu ia berbuat.

Menurut teori kehendak, sengaja adalah kehendak untuk mewujudkan unsurunsur delik dalam rumusan undang-undang. Sebagai contoh, A mengarahkan pistol kepada B dan A menembak mati B; A adalah "sengaja" apabila benar-benar menghendaki kematian B.

\footnotetext{
${ }^{42}$ Roeslan Saleh, Op.Cit, h.71

${ }^{43}$ Ibid, h. 73
} 


\section{Jurnal Ilmiah METADATA}

Menurut Van Hattum opzet ( sengaja) secara ilmu bahasa berarti oogemark (maksud), dalam arti tujuan dan kehendak menurut istilah undang-undang, opzetelijk (dengan sengaja) diganti dengan willens en watens (meghendaki dan mengetahui ). ${ }^{44}$

Pompe mengatakan, bahwa apabila orang mengartikan maksud (oogemark) sebagai tujuan (bedoeling) seperti rencana keinginan pembuat, berarti ada perbedaan antara maksud (oogemark) dan sengaja (opzet). Apabila maksud (oogemark) di batasi sampai tujuan terdekat (naaste doel) dari pembuat, berarti pengertian maksud (oogemark) selalu juga berarti sengaja (opzet) ${ }^{45}$

\section{F. Pertanggungjawaban Dan Penyelesaian Tindak Pidana Kampanye Di Luar Prosedur Dalam UU No. 8 Tahun 2012 dan Mekanisme Penyelesaian Dalam UU No. 8 Tahun 2012}

Untuk lebih jelas tentang pertanggungjawaban dan penyelesaian tindak pidana kampanye di luar prosedur dalam UU No. 8 Tahun 2012 dan mekanisme penyelesaian dalam UU No. 8 Tahun 2012, maka akan dianalisis suatu kasus putusan Pengadilan Negeri Medan No. 903 Pid.B/2009/PN.Mdn.

\section{Posisi Kasus}

Adapun duduk perkara dalam kasus ini adalah bahwa Yenny Pardede dan Ety Mulyati pada suatu waktu dalam bulan Januari 2009 bertempat di mesjid Al'ikhlas Jl. SM. Raja Gg. Ikhlas Medan yang termasuk dalam daerah hukum Pengadilan Negeri Medan secara sendiri-sendiri maupun bersama-sama dengan $\mathrm{H}$. Arso (berkas perkara terpisah) baik sebagai orang yang melakukan, yang menyuruh melakukan atau turut melakukan perbuatan yaitu dengan sengaa melanggar larangan pelaksanaan kampane pemilu yaitu melakuka perbuatan yaitu dengan sengaja melanggar larangan pelaksanaan kampanye pemilu yaitu menggunakan tempat ibadah, perbuatan mana dilakukan terdakwa dengan cara pada waktu dan tempat seperti tersebut di atas para terdakwa datang untuk mengikuti perwiritan ibu-ibu, setelah selesai mendengarkan

\footnotetext{
${ }^{44}$ Sudarto, Op. Cit, h. 88

${ }^{45}$ Ibid, h. 89
} 


\section{Jurnal Ilmiah METADATA}

ceramah ustad, terdakwa $\mathrm{Hj}$. Ety Mulyati menyampaikan sosialisasi cara memilih dan mencontereng serta memperkenalkan para caleg yang bakal dipilih pada pemilu nantinya kemudian terdakwa $\mathrm{Hj}$. Ety Mulyati menyampaikan visi misinya bila terpilih sebagai anggota DPRD serta berjanji akan memperbaiki fasilitas TK Il'ikhlas bila terpilih menjadi anggota DPRD.

Selanjutnya terdakwa Hj. Yenny Pardede, SE membagi-bagikan bingkisan berupa jilbab berikut kartu nama terdakwa $\mathrm{Hj}$. Ety Mulyati dan $\mathrm{Hj}$. Yenny Pardede, SE kepada seluruh ibu-ibu anggota perwirita yang hadir lebih kurang 50 (lima puluh) orang. Lalu H. Arso turut mensosialisasikan serta menghimbau ibu-ibu perwiritan untuk memilih terdakwa $\mathrm{Hj}$. Yenny Pardede, SE dan $\mathrm{Hj}$. Ety Mulyati pada saat pemilu nantinya dan menjanjika apabila terdakwa $\mathrm{Hj}$. Yenny Pardede, SE dan Hj. Ety Mulyati terpilih, maka fasilitas TK Al'Ikhlas akan diperbaiki.

2. Dakwaan/Tuntutan

Berdasarkan fakta-fakta yang terungkap dalam persidangam, maka Jaksa Penuntut Umum mendakwa Hj. Yenny Pardede dan Hj. Ety Mulyati dinyatakan telah melakukan tindak pidana melanggar perkara kampanye Pemilu Pasal 270 dan Pasal 274 sebagaimana diatur dalam Pasal 137 ayat (4) Undang-Undang Nomor 10 Tahun 2008 tentang Pemilihan Umum Anggota Dewan Perwakilan Rakyat, Dewan Perwakilan Rakyat Daerah, dan Dewan Perwakilan Rakyat Daerah.

Bahwa terdakwa $\mathrm{Hj}$. Yenny Pardede dan $\mathrm{Hj}$. Ety Mulyati dihadapkan ke pengadilan dengan dakwaan yang disusun secara alternatif oleh karenanya berdasarkan fakta-fakta yang terungkap dalam persidangan, maka terhadap perbuatan terdakwa terdakwa $\mathrm{Hj}$. Yenny Pardede dan $\mathrm{Hj}$. Ety Mulyati telah memenuhi pembuktian sebagaimana dalam dakwaan melanggar Pasal 270 Undang-Undang Nomor 10 Tahun 2008 jo. Pasal 55 ayat (1) e KUHP dengan unsur-unsur sebagai berikut :

a. Setiap orang. 


\section{로\}}

vavasing

\section{Jurnal Ilmiah METADATA}

Yang dimaksud setiap orang adalah merupakan subjek hukum atau pelaku suatu tindak pidana. Dengan kata lain setiap orang yang melakkan perbuatan pidana dan mampu bertanggungjawab dalam hukum.

Dalam perkara yang seddang diperiksa dan diadili di persidangan saat ini disebutkan selaku terdakwa adalah $\mathrm{Hj}$. Yenny Pardede dan $\mathrm{Hj}$. Ety Mulyati sebagaimana identitasnya tertera dalam surat dakwaan tertanggal 17 Maret 2009 dan telah dibenarkan oleh para terdakwa sehingga dengan demikian unsur setiap orang sebagai subjek hukum telah dipenuhi.

b. Dengan sengaja melanggar larangan pelaksanaan kampanye pemilu yaitu menggunakan tempat ibadah.

Kesengajaan disini haruslah ditafsirkan secara luas, jadi tidak semata-mata sebaai opzet als oogmerk (sengaja sebagai maksud) melainkan juga sebagai opzet met beustheid van zekerheid of noodzakelihkheid (sengaja dengan kesadaran tentang kepastian) ataupun sebagai opzet met waarshijnlijheidbewustzijn (sengaja dengan kesadaran kemungkinan sekali terjadi).

Bahwa dalam memori penjelasan (Memori Van Toeluchting) memberi arti sengaja (opzet) sebagai kehendak yang disadari yang ditunjukan untuk melakukan kejahatan tertentu. Sengaja sama dengan willens en wetens (dikehendaki dan diketahui). Dan yang dimaksud dengan kampanye pemilu adalah kegiatan peserta pemilu untuk meyakinkan para pemilih dengan menawarkan visi, misi dan program peserta pemilu.

c. Telah melakukan atau turut serta melakukan.

Bahwa unsur ini disusun secara alternatif yang memberikan kualifikasi seseorang dapat dihukum sebagai orang yang melakukan peristiwa pidana baik sebagai pelaku atau orang yang menyuruh melakukan (doen plegen) atau orang yang turut melakukan (medepleger) dalam arti bersama-sama melakukan dimana lebih dari satu orang yang semuanya melakukan perbuatan pelaksanaan secara bersama-sama. 


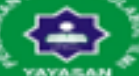

\section{Jurnal Ilmiah METADATA}

Berdasarkan uraian di atas, maka Jaksa Penuntut Umum berkesimpulan bahwa perbuatan terdakwa Hj. Yenny Pardede dan Hj. Ety Mulyati telah terbukti secara sah dan meyakinkan melakukan tindak pidana yaitu telah melakukan atau turut serta melakukan perbuatan melanggar larangan kampanye sebagaimana dimaksud dalam Pasal 270 UU RI No. 10 Tahun 2008 Tentang Pemilu jo. Pasal 55 ayat (1) ke Ie KUHP dalam surat dakwaan pertama.

Berdasarkan uraian diatas, maka Jaksa Penuntut Umum dalam perkara ini dengan memperhatikan ketentuan Undang-Undang yang bersangkutan menuntut supaya pengadilan Negeri Medan yang memeriksa dan mengadili perkara ini memutuskan :

a. Menyatakan terdakwa Hj. Yenny Pardede dan Hj. Ety Mulyati terbukti secara sah dan meyakinkan bersalah melakukan tindak pidana melanggar larangan pelaksanaan kampanye sebagaimana diatur dalam Pasal 270 UU RI No. 10 Tahun 2008 Tentang Pemilu jo. Pasal 55 ayat (1) ke Ie KUHP.

b. Menjatuhkan pidana terhadap terdakwa Pasal 55 ayat (1) ke Ie KUHP dengan pidana penjara masing-masing selama 6 (enam) bulan penjara dan membayar denda sebesar Rp. 6.000.000,- (enam juta rupiah) subsidair 3 (tiga) bulan kurungan.

c. Menetapkan baranb bukti berupa 1 (satu) buah kotak merek R \& R Production berisi jilbab dan 4 (empat) kartu nama masing-msing 2 (dua) lembar atas nama Hj. Yenny Pardede dan 2 (dua) lembar atas nama Hj. Ety Mulyati dirampas untuk dimusnahkan.

d. Membebankan kepada terdakwa Hj. Yenny Pardede dan Hj. Ety Mulyati agar membayar biaya perkara masing-masing sebesar Rp.1000,- (seribu rupiah).

2. Pertimbangan Hakim dan Putusan.

Menimbang bahwa setelah terungkap fakta-fakta dipersidangan sebagaimana diuraikan diatas, maka tibalah saatnya bagi Hakim untuk mempertimbangkan sampai 


\section{란?}

\section{Jurnal Ilmiah METADATA}

sejauh mana dakwaan Penuntut Umum tersebut dapat diterapkan terhadap diri Terdakwa tersebut.

Penuntut Umum dalam tuntutannya berpendapat bahwa dari dakwaan tersebut yang terbukti adalah dakwaan primair sebagaimana diatur dan diancam dalam Pasal Pasal 270 UU RI No. 10 Tahun 2008 Tentang Pemilu jo. Pasal 55 ayat (1) ke Ie KUHP.

Menimbang, bahwa bentuk dakwaan Penuntut Umum adalah berbentuk alternatif yang berarti bahwa apabila dalam dakwaan primair telah terbukti, maka untuk dakwaan berikutnya tidak perlu dipertimbangkan lagi dan sebaliknya apabila dakwaan primair tidak terbukti, maka dakwaan selanjutnya harus dipertimbangkan/dibuktikan.

Menimbang, bahwa Terdakwa dalam dakwaan primair telah didakwa oleh Penuntut Umum melanggar Pasal 270 UU RI No. 10 Tahun 2008 Tentang Pemilu jo. Pasal 55 ayat (1) ke Ie KUHP, yang unsur-unsurnya adalah sebagai berikut :

1. Setiap orang.

Yang dimaksud setiap orang adalah merupakan subjek hukum atau pelaku suatu tindak pidana. Dengan kata lain setiap orang yang melakkan perbuatan pidana dan mampu bertanggungjawab dalam hukum. Dalam perkara yang seddang diperiksa dan diadili di persidangan saat ini disebutkan selaku terdakwa adalah $\mathrm{Hj}$. Yenny Pardede dan $\mathrm{Hj}$. Ety Mulyati sebagaimana identitasnya tertera dalam surat dakwaan tertanggal 17 Maret 2009 dan telah dibenarkan oleh para terdakwa sehingga dengan demikian unsur setiap orang sebagai subjek hukum telah dipenuhi.

2. Unsur melanggar larangan dalam kampanye.

Menimbang bahwa larangan kampanye sebagaimana ditentukan dalam ketentuan Pasal 88 ayat (1) huruf a, b, c, d, e, f, g h dan huruf i bersifat alternatif dalam arti dengan terbuktiknya salah satu saja dari yang disebutkan dalam ketentuan tersebut, maka dianggap terbukti seluruhnya. 


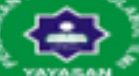

\section{Jurnal Ilmiah METADATA}

Menimbang, bahwa dalam fakta hukum sebagaimana telah diuraikan di atas para terdakwa para hari Sabtu tanggal 31 Januari 2009 sekira jam 16.30 Wib bertempat di mesjid Al-Ikhlas Jalan Sisingamangaraja Gang Ikhlas Medan, para terdakwa datang untuk mengikuti perwiritan ibu-ibu dan setelah selesai mendengarkan ceramah dari ustad, para terdakwa memperkenalkan diri sebagai caleg dari partai PPP dan sosialisasi cara memilih dengan mencontereng para caleg yang dipiih diantaranya nama para terdakwa tersebut dengan menunjukan kartu nama kemudian terdakwa $\mathrm{Hj}$. Ety Mulyati menyampaikan bahwa bagi anakanak yang kurang mampu perekonomian orang tuanya dapat disekolahkan pada sekolah yang terdakwa sebagai kepala sekolahnya dan terdakwa $\mathrm{Hj}$. Yenny Pardede membagi-bagikan bingkisan berupa jilbab lebih kurang 50 buah berikut kartu pengenal atas nama para terdakwa dan mohon doa restu serta dukungan untuk memperjuangkan para perempuan di legislatif.

Menimbang, bahwa dalam pembelaannya para terdakwa menyatakan bahwa perbuatan terdakwa tidak dapat dikualifisir sebagai kampanye karena tidak menyampaikan visi dan misi selain untuk perkenalan saja.

Menimbang, bahwa berdasarkan fakta-fakta tersebut menurut majelis hakim apa yang dilakukan oleh para terdakwa telah melanggar larangan kampanye sebagaimana ditentukan dalam Undang-Undang Nomor 10 Tahun 2008, hal mana sesuai dengan ketentuan Pasal 1 butir ke 26 yang menentukan bahwa kampanye pemilu adalah kegiatan peserta pemilu untuk meyakinkan para pemilih dengan menawarkan visi, misi dan program peserta pemilu dan jika dikaitkan dengan ketentuan Pasal 81 Undang-Undang Nomor 10 Tahun 2008 yang menentukan bahwa kampanye pemilu sebagaimana dimaksud dalam Pasal 76 dapat dilakukan melalui :

1) Pertemuan terbatas.

2) Pertemuan tatap muka

3) Media massa, cetak dan media massa elektronik. 


\section{\{의}

rarnsang

\section{Jurnal Ilmiah METADATA}

4) Pemasangan alat peraga di tempat umum

5) Rapat umum

6) Kegiatan lain yang tidak melanggar larangan kampanye dan peraturan perundang-undangan.

Menimbang, bahwa dengan demikian, maka kegiatan para terdakwa yang secara langsung maupun tidak langsung menyebarkan alat peraga berupa kartu tnda calon legislatif atas nama para terdakwa tersebut dapat dikualifikasikan sebagai kegiatan kampanye dan oleh karena dilakukan di tempat ibadah, maka perbuatan para terdakwa tersebut telah memenuhi unsur melanggar larangan kampanye oleh karena itu unsur ini telah terbukti.

3. Unsur yang dilakukan oleh dua orang atau lebih secara bersama-sama

Menimbang, bahwa unsur ini dalam teori hukum pidana disebut deelneming yang artinya apabila dalam satu delik tersangkut beberapa orang atau lebih dari satu orang.

Menimbang, bahwa bentuk perbuatan yang diatur dalam Pasal 55 KUHP antara lain pembuat tindak pidana ke-1 : mereka yang melakukan, menyuruh melakukan, turut serta melakukan adalah mereka yang turut melakukan tindak pidana adalah mereka dengan sengaja bersama-sama melakukan tindak pidana, jadi dalam pelaksanaan ada kerjasama yang erat antar mereka, maka untuk dapat menentukan apakah pelaku turut serta melakukan atau tidak,maka tidak melihat kepada perbuatan masing-masing pelaku secara satu persatu dan berdiri sendiri melainkan melihat semua sebagai kesatuan.

Menimbang, bahwa sesuai dengan fakta hukum yang telah diuraikan di atas, bahwa para terdakwa secara bersama-sama di Mesjid Al-Ikhlas untuk mengikuti kegiatan perwiritan ibu-ibu dan setelah selesai mendengarkan ceramah dari ustad, para terdakwa memperkenalkan diri sebagai caleg dari partai PPP dan sosialisasi cara memilih dan mencontereng para caleg yang dipilih diantaranya nama para terdakwa tersebut dengan menunjukan kartu nama kemudian terdakwa 


\section{라}

\section{Jurnal Ilmiah METADATA}

Hj. Ety Mulyati menyampaikan bahwa bagi anak-anak yang kurang mampu perekekonomian orang tuanya dapat disekolahkan pada sekolah yang terdakwa sebagai kepala sekolahnya dan terdakwa H. Yeni Pardede membagi-bagikan bignkisan berupa jilbab lebih kurang 50 buah berikut kartu pengenal atas nama para terdakwa dan mohon doa restu dan dukungan. Dengan demikian unsur ini telah terbukti.

Menimbang, bahwa sebagai dasar penjatuhan pidana kepada diri terdakwa dipertimbangkan hal-hal yang memberatkan dan meringankan sebagai berikut :

Hal-hal yang memberatkan :

Perbuatan para terdakwa sebagai calin lembaga legislatif tidak memberikan pembelajaran politik yang baik kepada masyarakat khususnya ibu-ibu.

Hal-hal yang meringkankan :

1. Kedatangan para terdakwa ke Mesjid Al-Ikhlas atas undangan warga masyarakat.

2. Para terdakwa adalah calon legislatif pemula tentu kurang berpengalaman dan berupaya memperoleh dukungan dari lingkungan pergaulannya.

3. Para pelapor menyatakan mencabut laporannya.

Menimbang, bahwa selain itu peru juga dipertimbangkan bahwa dalam doktrin ditentukan bahwa penjatuhan pidana perampasan kemerdekaan kepada pelaku tindak pidana merupakan ultimum remidium yang berarti bahwa penjatuhan pidana penjara merupakan obat terakhir dalam hal pelaku tindak pidana tidak memungkinkan untuk dijatuhi pidana dengan jenis pidana denda maupun pidana bersyarat artinya dalam penjatuhan pidana kepada para terdakwa perlu adanya diagnosa jenis pidana apa yang paling tepat dijatuhkan kepada para terdakwa sehingga penjatuhan pidana efektif untuk mencapai tujuan pemidanaan yang dalam hukum pidana modern mengarahkan pemidanaan pada pembinaan pada pelaku dan bukan sebagai balas dendam dan pembinaan terhadap para terdakwa tidak harus dilakukan di dalam tembik lembaga pemasyarakatan tetapi dapat dikalukan di luar dengan tetap mendapat pengawasan atau pembinaan dari Bapas. 


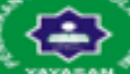

Jurnal Ilmiah METADATA

\section{KESIMPULAN}

Pertanggungjawaban pidana pelaku tindak pidana pemilu dalam KUHP adalah apabila melakukan ancaman kekerasan, merintangi seseorang melakukan hak pilihnya, melakukan penyuapan terhadap seseorang dengan maksud agar tidak menjalankan hak pilihnya, melakukan penipuan yang menyebabkan hak pilih seseorang menjadi tidak berharga, melakukan pemalsuan identitas dan melakukan penipuan yang menyebabkan hasil pemungutan suara menjadi lain seolah-olah suarasuara yang diberikan sah.

Pertanggungjawaban dan penyelesaian tindak pidana kampanye di luar prosedur dalam UU No. 8 Tahun 2012 dan mekanisme penyelesaian dalam UU No. 8 Tahun 2012 yang dilakukan Yenny Pardede da Ety Mulyati dinyatakan telah melakukan tindak pidana melanggar perkara kampanye Pemilu Pasal 270 dan Pasal 274 sebagaimana diatur dalam Pasal 137 ayat (4) Undang-Undang Nomor 10 Tahun 2008 tentang Pemilihan Umum Anggota Dewan Perwakilan Rakyat, Dewan Perwakilan Rakyat Daerah, dan Dewan Perwakilan Rakyat Daerah.

\section{DAFTAR PUSTAKA}

\section{A. Buku}

Adami Chazawi., Pelajaran Hukum Pidana Bagian I, PT. Raja Grafindo Persada, Jakarta, 2000.

Andi Hamzah, Bunga Rampai Hukum Pidana dan Acara Pidana, Ghalia Indonesia Jakarta, 1986,

B. Simanjuntak., Pengantar Kriminologi dan Pathologi Sosial, Tarsito, Bandung, 1992

Djoko Prakoso., Tindak Pidana Pemilu, Rajawali Pers, Jakarta, 2001.

; Asas-asas Hukum Pidana di Indonesia. Liberty, Yogyakarta, 1987. 


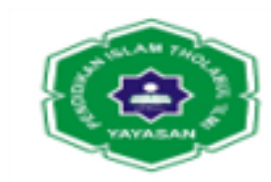

Jurnal Ilmiah METADATA

J.E. Sahetapy, Victimilogy Sebuah Bunga Rampai, Sinar Harapan, Jakarta, 1998

Made Darma Weda., Kriminologi, PT. Raja Grafindo Persada, Jakarta, 1996.

Mulyatno, Asas-Asas Hukum Pidana, Bina Aksara, Jakarta, 1987.

M. Hamdan., Tindak Pidana Suap dan Money Politics, Pustaka Bangsa Press, Medan, 2005.

R. Herlambang Perdana Wiratraman, Pemilihan Umum, Fakultas Hukum, Universitas Airlangga, Surabaya, 2008.

R. Soesilo,Kitab Undang-Undang Hukum Pidana, Politea, Bogor, 1998.

Roeslan Saleh, Perbuatan Pidana dan Pertanggungjawaban Pidana, Aksara Baru, Jakarta, 1983

R. Wirjono Prodjodikoro, Tindak-Tindak Pidana Tertentu Dalam KUH.Pidana Indonesia, Eresco,Bandung, 2002

Sudarto, Hukum Pidana dan Perkembangan Masyarakat, Sinar Baru, Bandung, 1983.

Sintong Silaban,Tindak Pidana Pemilu,Jakarta,Pustaka Sinar Harapan, 1999

Soedjono Dirdjosisworo., Ruang Lingkup Kriminologi, Remadja Karya, Bandung, 1996.

S.R Sianturi, Asas-asas Hukum Pidana Indonesia dan Penerapanya, Alumni Ahaem-Peteheam, Jakarta, 1996

Topo Santoso, Tindak Pidana Pemilu, Jakarta, Sinar Grafika,2006.

Tomi Tresnady, Modul Pemilihan Umum untuk Pemula, Sinar Grafiti, Jakarta, 2010.

\section{B. Undang-Undang}

Undang-Undang Nomor 8 Tahun 2012 Tentang Pemilihan Umum Anggota Dewan Perwakilan Rakyat, Dewan Perwakilan Daerah, Dan Dewan Perwakilan Rakyat Daerah. 